\title{
SISTEM INFORMASI AKUNTANSI PENERIMAAN DAN PENGELUARAN KAS PADA KPRI ANDAN JEJAMA KABUPATEN PESAWARAN
}

\author{
Damayanti $^{1)}$, M.Yusuf Hernandez ${ }^{2)}$ \\ ${ }^{1)}$ Sistem Informasi, Universitas Teknokrat Indonesia \\ ${ }^{2)}$ Sistem Informasi Akuntansi, Universitas Teknokrat Indonesia \\ Jl. H.ZA Pagaralam, No 9-11, Labuhan ratu, Bandarlampung \\ Email : damayanti@teknokrat.ac.id ${ }^{1)}$,yusuf.hernandez11@gmail.com ${ }^{2)}$
}

\begin{abstract}
Abstrak
KPRI Andan Jejama adalah merupakan salah satu koperasi di Lampung yang bergerak di bidang jasa simpan pinjam. Seperti koperasi pada umumnya yang menerapkan sistem informasi penerimaan dan pengeluaran kas. Penerimaan kas pada KPRI Andan Jejama salah satunya berasal dari angsuran piutang anggota, sedangkan pengeluaran kas diantaranya pemberian pinjaman kepada anggota dan biaya oprasional kantor. Dalam proses penerimaan dan pengeluaran kas dibutuhkan dokumen awal yang digunakan yaitu dokumen yang berisi tentang data anggota dan data karyawan. Bagian bidang keuangan bertugas untuk mencatat data anggota yang ingin melakukan penyetoran pinjaman dan mencatat bukti kas masuk serta membuat jurnal penerimaan kas dan pengeluaran kas perbulan menggunakan microsoft excel. Kemudian diserahkan kepada bagian bidang pembukuan untuk dicatat dalam buku besar. Penyimpanan bukti penerimaan kas dan bukti pengeluaran kas belum menggunakan database management system. Hal tersebut menjadi kendala ketika pencarian data saat dibutuhkan karena dokumen tersebut ditumpuk sehingga penyampaian informasi yang dibutuhkan oleh bagian bidang pembukuan dan pimpinan seringkali mengalami keterlambatan. Untuk mengatasi masalah tersebut maka dibangun sistem informasi akuntansi penerimaan dan pengeluaran kas pada KPRI Andan Jejama dengan menggunakan metode pengembangan sistem waterffal. Pengumpulan data menggunakan teknik observasi, wawancara dan studi pustaka. Pada tahap requirement analysis dan defenisi melakukan analisis kebutuhan sistem. Hasil penelitian ini menghasilkan aplikasi sistem akuntansi penerimaan dan pengeluaran kas pada KPRI Andan Jejama. Sehingga membantu memudahkan karyawan dalam pengelolaan data penerimaan kas dan pengeluaran kas, mempercepat dalam penyajian laporan dan mempermudah dalam proses pencarian data kas masuk dan kas keluar pada KPRI Andan Jejama Kabupaten Pesawaran.
\end{abstract}

Kata kunci: Sistem informasi akuntansi, penerimaan kas, pengeluaran kas, kas masuk, kas keluar.

\section{Pendahuluan}

Perkembangan teknologi komputer saat ini telah berkembang secara pesat seiring dengan meningkatnya kebutuhan manusia terhadap teknologi dan informasi disegala bidang. Adapun kelebihan yang didapat dari pengolahan data menggunakan sistem terkomputerisasi yaitu dapat mengolah data dengan cepat dan akurat, dapat mengolah data dalam kapasitas besar, dapat menyimpan arsip atau file dengan baik tanpa menggunakan tempat yang banyak. Perusahaan telah menggunakan sistem komputer untuk mencatat semua transaksi sehingga data tersedia secara otomatis, lebih efektif dan efisien bagi perusahaan (Erteria, N. W., dkk, 2016). Menurut Diana, A dan Setiawati, L (2010), Sistem Informasi akuntansi adalah sistem yang bertujuan untuk mengumpulkan dan memproses data serta melaporkan informasi yang berkaitan dengan transaksi keuangan (Mulyadi, 2016)

Pada saat ini KPRI Andan Jejama bergerak di bidang jasa simpan pinjam. Penerimaan kas pada KPRI Andan Jejama salah satunya berasal dari angsuran piutang anggota, sedangkan pengeluaran kas diantaranya pemberian pinjaman kepada anggota dan biaya oprasional kantor. Dalam proses penerimaan dan pengeluaran kas dibutuhkan dokumen awal yang digunakan yaitu dokumen yang berisi tentang data anggota dan data karyawan. Bagian bidang keuangan bertugas untuk mencatat data anggota yang ingin melakukan penyetoran pinjaman dan mencatat bukti kas masuk serta membuat jurnal penerimaan kas dan pengeluaran kas perbulan menggunakan microsoft excel. Kemudian diserahkan kepada bagian bidang pembukuan untuk dicatat dalam buku besar. Penyimpanan bukti penerimaan kas dan bukti pengeluaran kas belum menggunakan database management system. Hal tersebut menjadi kendala ketika pencarian data saat dibutuhkan karena dokumen tersebut ditumpuk sehingga penyampaian informasi yang dibutuhkan oleh bagian bidang pembukuan dan pimpinan seringkali mengalami keterlambatan. Sistem informasi penerimaan dan pengeluaran kas penting bagi KPRI Andan Jejama. Dengan sistem informasi penerimaan kas dan pengeluaran kas diharapkan akan meningkatkan efektifitas dan efisiensi kerja. Sehingga membantu memudahkan karyawan dalam pengelolaan data penerimaan kas dan pengeluaran kas, mempercepat dalam penyajian laporan dan mempermudah dalam proses pencarian data kas masuk dan kas keluar pada KPRI Andan Jejama Kabupaten Pesawaran. Seperti halnya pada penelitian Damayanti dan Sulistiani, Heni 
(2017) Sistem penerimaan kas dapat mempermudah dalam pencarian data, mempermudah dan mempercepat dalam penyajian laporan sehingga pimpinan dapat segera mengambil keputusan berdasarkan laporan yang diterima. Sistem informasi akuntansi penerimaan dan pengeluaran kas dapat dilaksanakan secara sistematis (Saifudin, Ardani, F. P, 2017).

\section{Pembahasan}

Sistem informasi penerimaan dan pengeluaran kas pada KPRI Andan Jejama dibangun dengan menggunakan metode pengembangan sistem waterffal dengan tahapan requirement analysis dan defenisi, system and software design, implementasi and unit testing, integration and system testing, maintenance (Sommerville, 2011). Pada penelitian ini tidak sampai pada tahap maintenance. Metodologi pengembangan sistem adalah metodemetode, prosedur-prosedur, konsep-konsep pekerjaan dan aturan-aturan untuk mengembangkan suatu sistem informasi (Sutabri, 2012). Pengumpulan data menggunakan teknik observasi, wawancara dan studi pustaka.

Pada tahap requirement analysis dan defenisi dengan melakukan analisis kebutuhan sistem dimana terdiri dari dua yaitu kebutuhan fungsional dan non fungsional.

\section{A. Analisis Kebutuhan fungsional}

Analisis kebutuhan fungsional adalah kebutuhan yang berisi proses-proses dan informasi apa saja yang nantinya dilakukan dan dihasilkan oleh sistem. Dalam kebutuhan fungsional ini, aplikasi yang dirancang sesuai dengan kebutuhan yang diharapkan dapat berjalan pada KPRI Andan Jejama. Berikut analisis kebutuhan fungsional:

1. Sistem dapat mengolah data anggota

2. Sistem dapat mengolah data karyawan.

3. Sistem dapat mengolah data kas masuk, data kas keluar, data saldo kas,

4. Sistem dapat menampilkan laporan jurnal kas masuk

5. Sistem dapat menampilkan laporan jurnal kas masuk

6. Sistem dapat menyajikan bukti penerimaan kas

\section{B. Analisis Kebutuhan Non Fungsional}

Analisis kebutuhan non fungsional adalah kebutuhan yang berisi properti yang dimiliki oleh sistem meliputi kebutuhan perangkat keras dan perangkat lunak. Perangkat keras yang digunakan yaitu Monitor, Hardisk minimal 320GB, Processor Intel Core 2 Duos, RAM (Random Access Memory) minimal 4GB, Mouse, Keyboard dan Printer. Sedangkan Spesifikasi perangkat lunak yang dibutuhkan yaitu Windows 7, Netbeans IDE 8.0, Database MySQL dan I-Report 6. Selain itu dilakukan analisis sistem penerimaan dan pengeluaran kas yang berjalan saat ini.
Selain analisis kebutuhan sistem juga dilakukan analisis pada sistem berjalan pada KPRI Andan Jejama pada kas keluar dan kas masuk. Dimulai dari karyawan memberikan bukti pembelian, pembelian tersebut merupakan pengeluaran bagi bidang keuangan, kemudian bidang keuangan membuatkan bukti pengeluaran kas 3 rangkap, bukti pengeluaran kas 1 dan 2 di arsipkan menurut tanggal dan bukti pengeluaran kas 3 di serahkan ke karyawan (penerima). Lalu bukti pengeluaran kas 1 dan 2 yang di arsipkan kemudian di inputkan kedalam komputer dengan menggunakan microsoft excel kemudian setelah akhir bulan bidang keuangan mencetak jurnal pengeluaran kas, kemudian bidang keuangan mengirimkan bukti pengeluaran kas 1 , 2 dan jurnal pengeluaran kas ke pimpinan untuk di lakukan otorisasi, setelah di otorisasi oleh pimpinan, pimpinan mengirimkan kembali ke bagian bidang keuangan untuk di arsipkan menurut tanggal. Prosedur sistem pengeluaran kas saat ini pada KPRI Andan Jejama dapat dilihat pada gambar 1 .

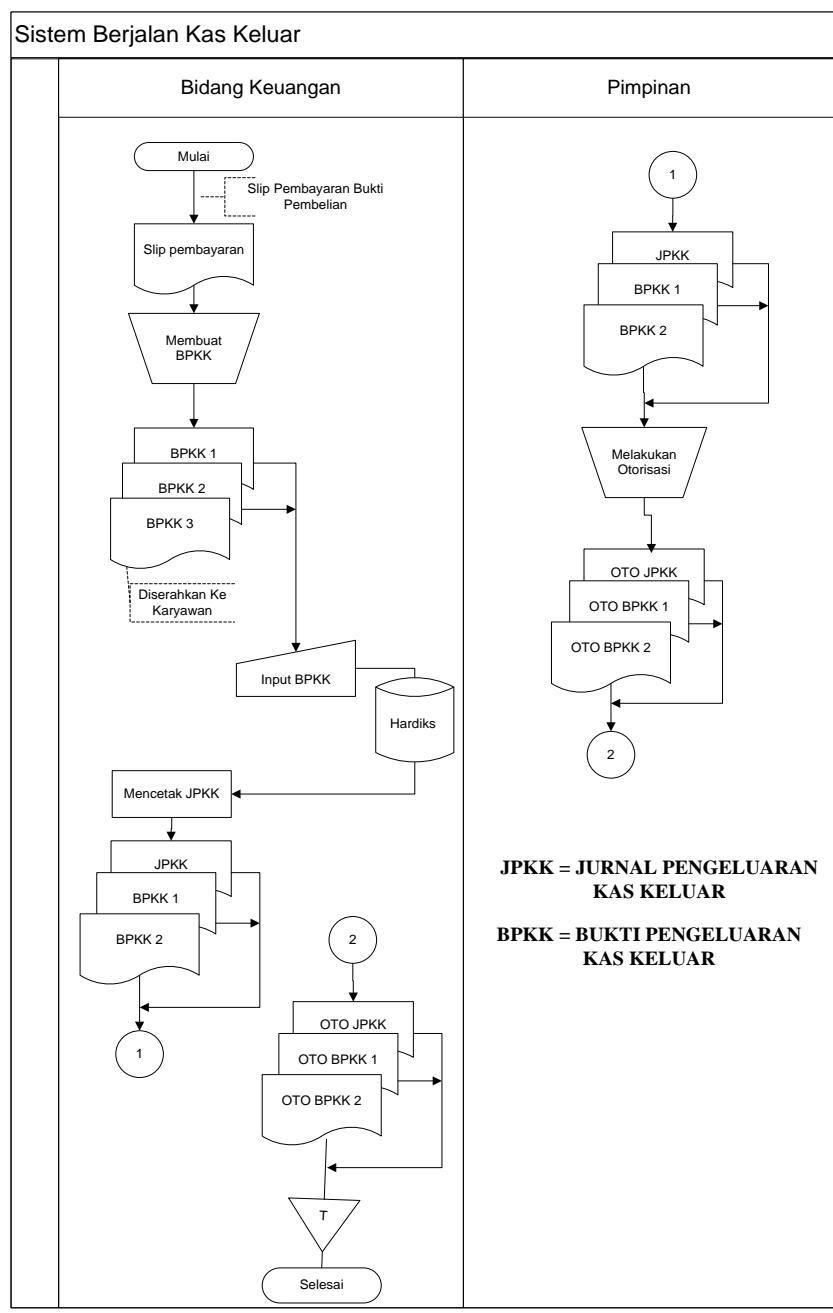

Gambar 1. Flowchart Sistem Berjalan Kas Keluar Sumber: KPRI Andan Jejama

Pemodelan sistem menggunakan use case dan activity diagram. Use Case atau diagram use case merupakan pemodelan untuk kelakuan (behavior) sistem informasi yang akan dibuat. Use case mendeskripsikan sebuah 
interaksi antara satu atau lebih aktor dengan sistem informasi yang akan dibuat (Rossa dan Shalahuddin, 2014). Berikut activity diagram pada sistem informasi penerimaan dan pengeluaran kas pada KPRI Andan Jejama. Activity diagram digunakan untuk menunjukkan siapa melakukan apa dengan teknik partition dapat dilihat pada gambar 2. Pada sistem ini terdapat dua aktor yaitu: Bagian keuangan dan pimpinan. Bagian keuangan melakukan login, setelah melakukan login bagian keuangan dapat mengolah data anggota, data karyawan, data kas masuk, dan kas keluar. Selanjutnya bidang keuangan dapat mengolah laporan jurnal penerimaan kas dan laporan jurnal pengeluaran kas. Sedangkan pimpinan hanya dapat melihat laporan jurnal penerimaan kas dan laporan jurnal pengeluaran kas.

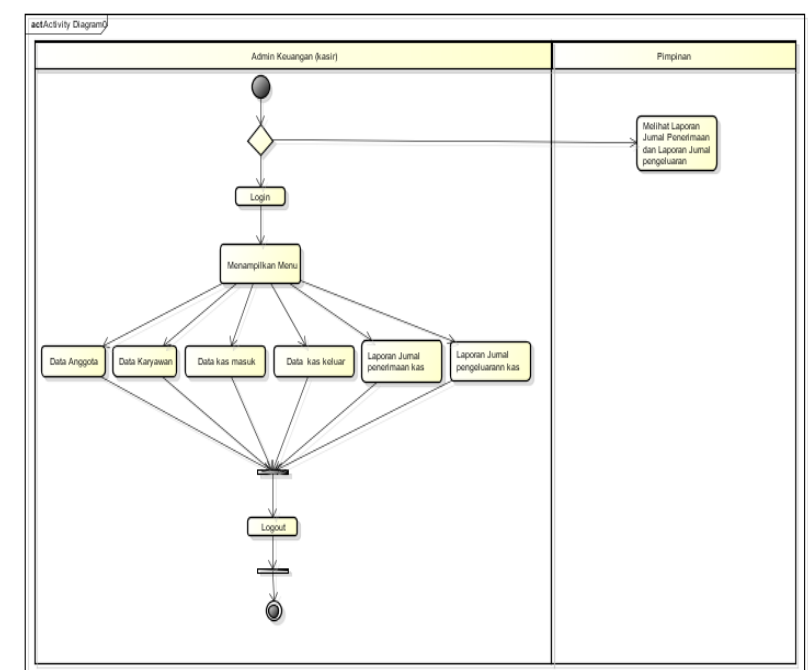

Gambar 2. Activity Diagram

\section{Hasil Penelitian}

Hasil penelitian ini adalah sebuah aplikasi sistem penerimaan dan pengeluaran kas pada KPRI Andan Jejama yang terdiri dari menu-menu sebagai beikut:

\section{Menu Login}

Menu Form Login merupakan tampilan awal untuk masuk ke menu utama, dengan memilih user dan memasukan password, maka user dapat mengakses program Sistem penerimaan dan pengeluaran kas pada KPRI Andan Jejama Pesawaran. Apa bila password salah, maka user tidak dapat mengakses program aplikasi Sistem penerimaan dan pengeluaran kas pada KPRI Andan Jejama. Form Login dapat dilihat pada gambar berikut ini :

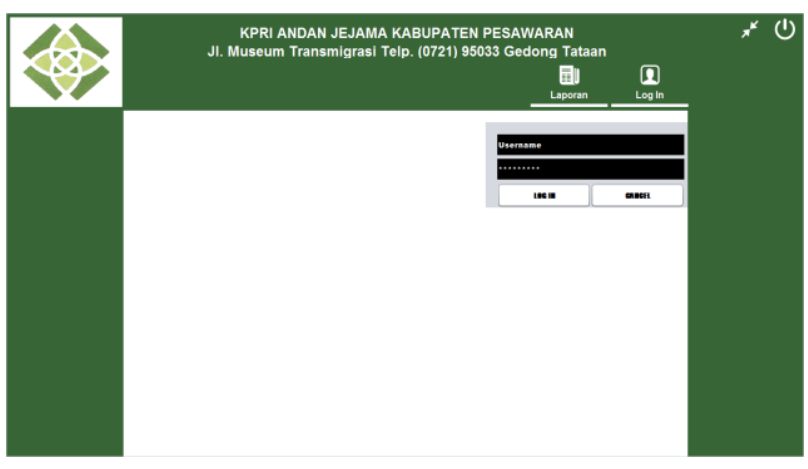

Gambar 3. Tampilan Menu Login

\section{Tampilan Menu Utama}

Form utama merupakan halaman utama yang terdiri dari File, master, transaksi, laporan. Untuk menampilkan program yang diinginkan dapat di klik pada sub menu pada menu utama. Form Menu Utama dapat dilihat pada gambar berikut

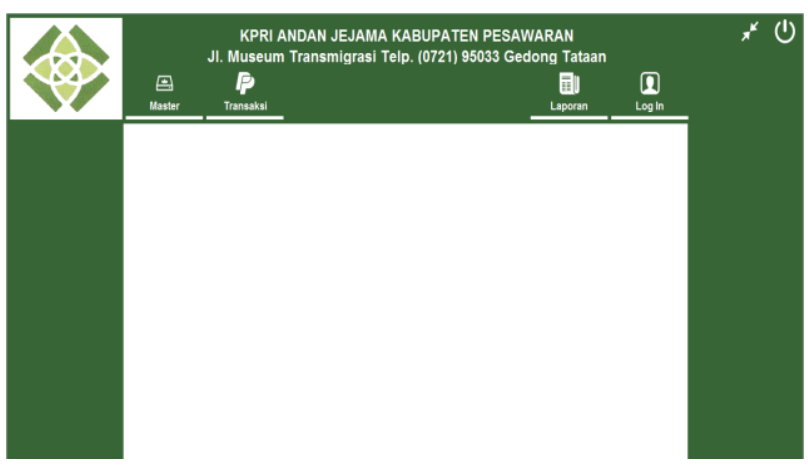

Gambar 4. Menu Utama

\section{Tampilan Menu Anggota}

Form data anggota merupakan form yang berisikan tentang data anggota. Form ini digunakan ketika akan menambah, mengubah, mencari, dan menghapus data anggota. Selain itu, user juga dapat melakukan pencarian data untuk proses yang sudah inputkan. Adapun data yang terdapat dalam form data anggota adalah kode anggota, dan nama anggota. Data anggota dapat dilihat pada gambar berikut ini:

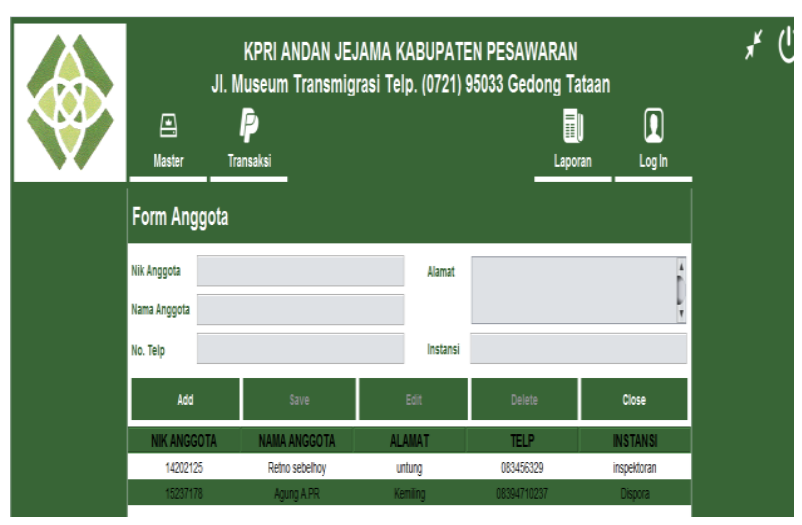

Gambar 5. Tampilan Menu Anggota 


\section{Tampilan Menu Karyawan}

Form Data karyawan merupakan form yang berisikan tentang data karyawan. Form ini digunakan ketika akan menambah, mengubah, mencari, dan menghapus data karyawan. Adapun data yang terdapat dalam Form Data karyawan dapat dilihat pada gambar berikut ini:

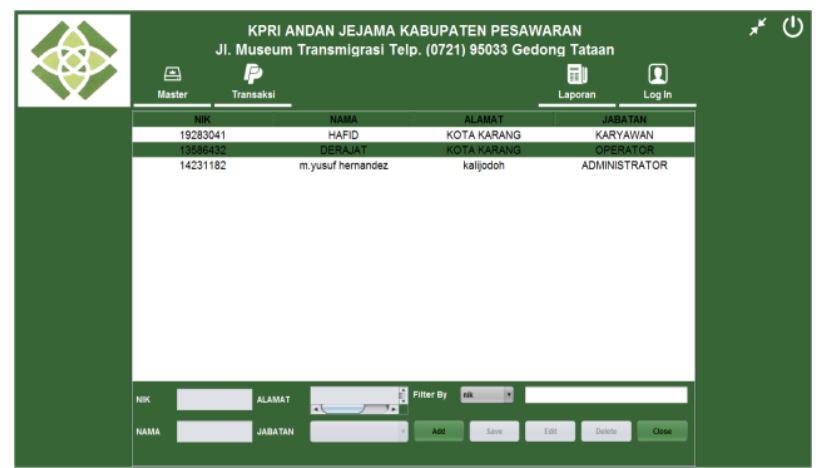

Gambar 6. Tampilan Menu Karyawan

\section{Tampilan Menu Kas Masuk}

Form Data transaksi merupakan form yang berisikan tentang data transaksi. Form ini digunakan ketika akan baru, simpan, mengubah, menghapus, cetak, dan keluar. Form Data kas masuk dapat dilihat pada gambar berikut ini

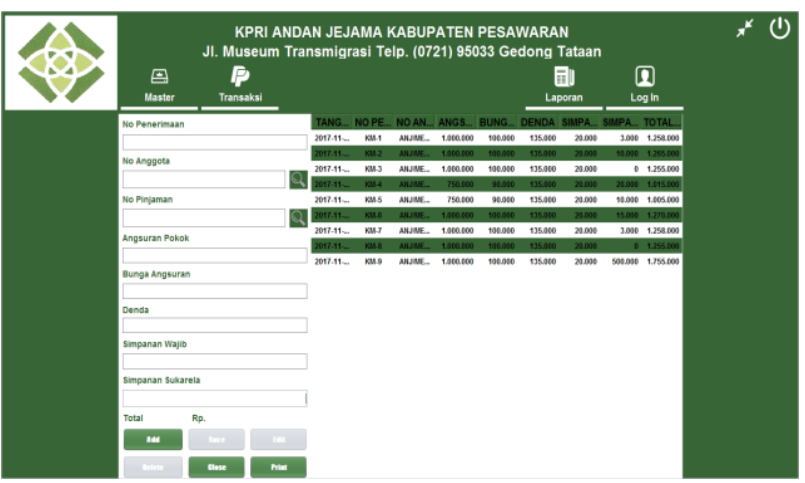

Gambar 7. Tampilan Menu Kas Masuk

\section{Tampilan Menu Kas Keluar}

Form Data transaksi Kas Keluar merupakan form yang berisikan tentang data transaksi. Form ini digunakan ketika akan baru, simpan, cetak, dan keluar. Form Data kas masuk dapat dilihat pada gambar berikut ini :

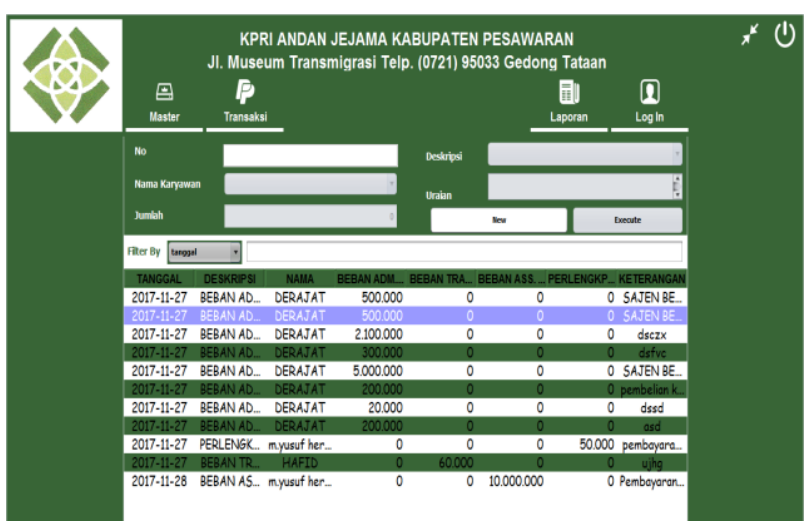

Gambar 8. Tampilan Menu Kas Keluar

\section{Tampilan Laporan Jurnal Pengeluran Kas}

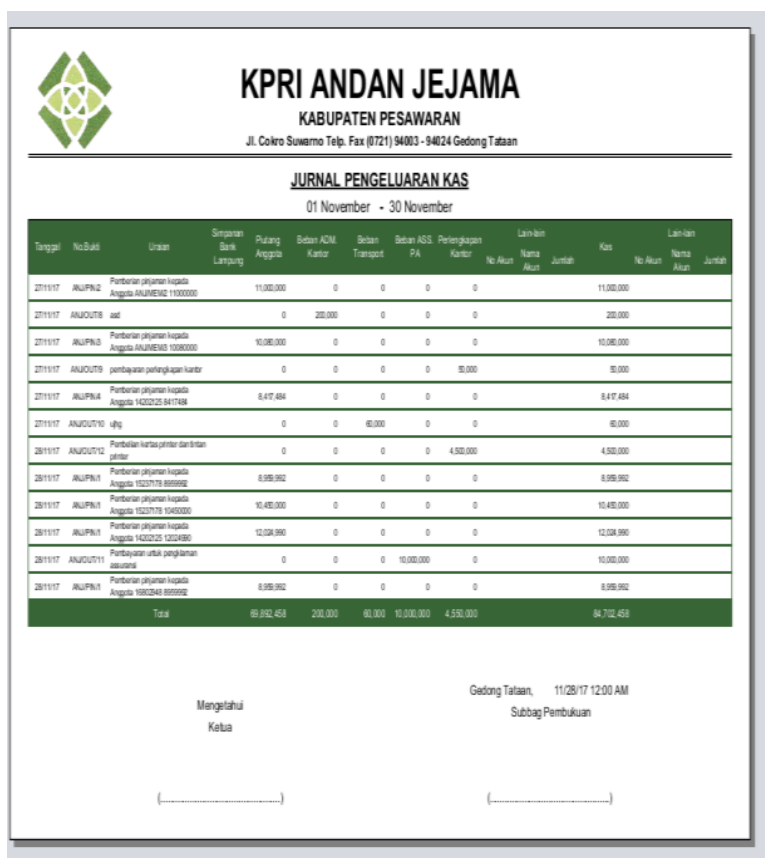

Gambar 9. Tampilan Laporan Jurnal Pengeluaran Kas

\section{Tampilan Laporan Jurnal Penerimaa kas}

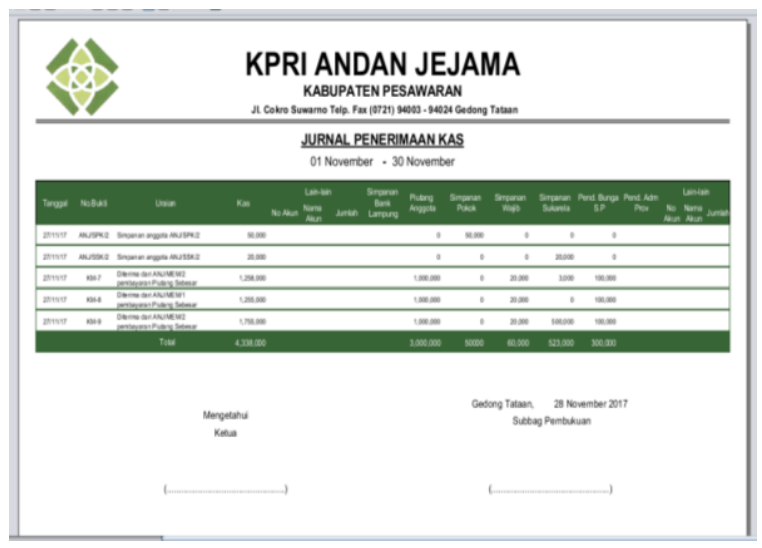

Gambar 10. Tampilan Laporan Jurnal Penerimaan Kas 


\section{Tampilan Bukti Penerimaan Kas}

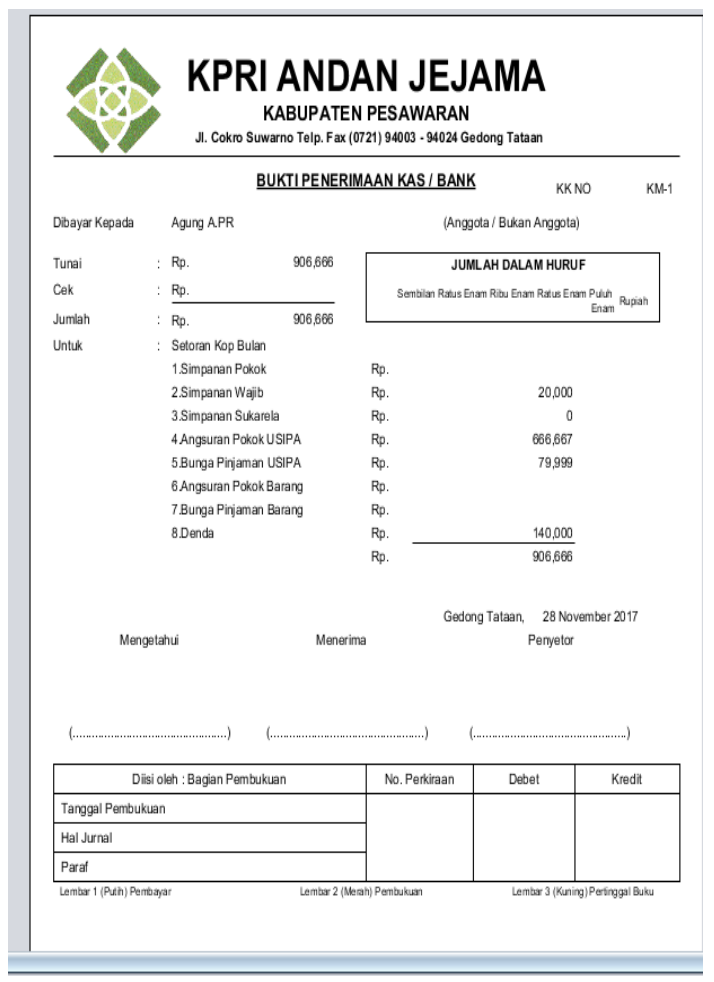

Gambar 11. Slip Penerimaan Kas

\section{Kesimpulan}

Berdasarkan penelitian yang telah dilakukan maka dapat disimpulkan bahwa dengan adanya aplikasi sistem infromasi penerimaan dan pengeluaran kas pada KPRI Andan Jejama dapat memudahkan karyawan dalam pengelolaan data penerimaan kas dan pengeluaran kas, mempercepat dalam penyajian laporan dan mempermudah dalam proses pencarian data kas masuk dan kas keluar pada KPRI Andan Jejama Kabupaten Pesawaran sehingga dapat meningkatkan efektifitas dan efisiensi kerja.

\section{Daftar Pustaka}

Damayanti dan Sulistiani, H. (2017) 'Sistem Informasi Pembayaran Biaya Sekolah Pada sd Ar-raudah Bandar Lampung', Jurnal TeknoInfo, Vol. 11, No. 2, 1-5.

Diana, A dan Setiawan, L. (2010) Sistem Informasi Akuntansi. Yogyakarta: Andi.

Esteria, N. W., dkk, (2016) 'Analisis Sistem Akuntansi Penerimaan dan Pengeluaran Kas Pada PT Hasjrat Abadi Manado. Jurnal Berkala Ilmiah Efisiensi Vol. 16 No. 04, 1087-1097

Mulyadi, (2016) Sistem Akuntansi. Edisi Keempat. Salemba empat. Jakarta

Rosa, A.S., dan Shalahudin. (2013) Rekayasa Perangkat Lunak Terstruktur dan Berorientasi Objek. Modula, Bandung

Syaifudin dan Ardani, F.P. (2017) 'Sistem Informasi Akuntansi Penelrimaan dan Pengeluran dalam
Meningkatkan Pengendalian Internal Atas Pendapatan Pada RSUP Dr. Kariadi Semarang'. Jurnal Riset Akuntansi Keuangan, Vol. 2 No. 2.,

Sutabri, T. (2012) Analisa Sistem Informasi. Yogyakarta: Andi Yogyakarta.

Sommerville, 2011, Software Engenering, United State of America, Pearson Education. 